\title{
Ciało i sport w twórczości Jana Szymczyka w kontekście klasycznych i współczesnych koncepcji socjologii ciała
}

$\bigvee \begin{aligned} & \text { centrum zainteresowania współczesnej kultury i nauki coraz bardziej } \\ & \text { eksponowane miejsce zajmuje cielesność. Ciało od dawna było obecne }\end{aligned}$ w nauce, kulturze, sztuce czy religii. Interesowano się ciałem żywym i martwym, młody i starym. Wraz z rozwojem medycyny, higieny życia codziennego, profilaktyki chorób zaczęło ono zyskiwać na znaczeniu, z jednej strony jako potencjał biologiczny umożliwiający coraz dłuższe i sprawne funkcjonowanie w pracy i w życiu codziennym ${ }^{1}$, z drugiej - jako potencjał kulturowy opracowywany i rozwijany w postaci społecznie utrwalonych schematów zachowania się osadzonych w szerszym społecznym kontekście ${ }^{2}$. Od lat osiemdziesiątych XX w. somatycznością zajmuje się wyodrębniona przez Bryana S. Turnera socjologia ciała. Od czasu ukazania się jego monografii The Body and Society w dyskursie naukowym pojawiło się wiele poglądów i przekonań dotyczących zagadnień ciała i cielesności, a na rynku wydawniczym cała seria książek i artykułów o tej tematyce. W polskiej dyskusji naukowej poświęconej ciału i cielesności można mówić o stale rozwijającym się dyskursie, w którym swój udział miał Jan Szymczyk.

* Dr hab. Monika Dorota Adamczyk - Katedra Socjologii Struktur, Procesów Społecznych i Pracy Socjalnej, Katolicki Uniwersytet Lubelski Jana Pawła II, e-mail: monika.adamczyk@kul.pl, ORCID: 0000-0002-1331-6026.

${ }^{1}$ D.L. Andrews, Desperately Seeking Michel. Foucault's Genealogy, the Body, and Critical Sport Sociology, „Sociology of Sport Journal” 1993, t. 10, nr 2, s. 148-167.

${ }^{2}$ M. Womack, The Anthropology of Health and Healing, AltaMira Press, Lanham-New York-Toronto-Plymouth UK 2010, s. 21-23. 
Celem niniejszego artykułu jest przedstawienie refleksji J. Szymczyka dotyczących statusu ciała w ponowoczesnym świecie i jego związków ze sportem i turystyką. W niektórych pismach lubelski socjolog poddaje systematycznej analizie status ciała w ponowoczesności i prezentuje powiązania cielesności ze sportem, turystyką i zdrowiem. Po zaprezentowaniu genezy rozwoju subdyscypliny socjologii ciała, determinantów jej rozwoju, przedmiotów jej zainteresowania, przedstawiony zostanie autorski wkład J. Szymczyka w wykazanie związku pomiędzy sportem, turystyką, zdrowiem a wspomnianą subdyscypliną socjologii.

\section{Status ciała w ponowoczesnej rzeczywistości}

Jak zauważa Honorata Jakubowska, zachodzące w czasie przemiany statusu ciała powinny być analizowane z perspektywy szerokich przemian społecznych, kulturowych, ekonomicznych i technologicznych ${ }^{3}$. Autorka zalicza do nich wzrost indywidualizmu i zwiększenie roli jednostki, rozwój społeczeństwa konsumpcyjnego, emancypację kobiet, przemiany obyczajowości, rozwój nauki i technologii, medykalizację 4 . Za jedną z kluczowych przyczyn wzrastającego zainteresowania ciałem uznaje się rozwój kultury konsumpcyjnej i przejście od ciężkiej pracy zgodnej z ideałem protestanckim ${ }^{5}$ do hedonizmu ${ }^{6}$. Nie tylko zmiana stylu życia związana $\mathrm{z}$ konsumpcją dóbr i wzrostem znaczenia czasu wolnego w życiu człowieka miała wpływ na redefiniowanie cielesności, nie mniej ważne okazało się coraz większe znaczenie wyglądu zewnętrznego. Kształt ciała, odpowiednia waga, sprawność fizyczna nabrały ogromnego znaczenia zarówno dla kształtowania tożsamości jednostkowej, jak i grup społecznych. Mike Featherstone wskazuje na jeszcze jeden ważny proces, niewątpliwie mający wpływ na zmiany w postrzeganiu cielesności, a mianowicie starzenie się „późnych społeczeństw kapitalistycznych". Proces starzenia się społeczeństw zachodnich zainicjował nowy dyskurs na poziomie naukowym, społecznym oraz gospodarczym, związany z dietami przeznaczonymi dla ludzi starszych, ich aktywnością fizyczną i kosmetykami dedykowanymi seniorom w jednym celu - zmiany ich starzejących się ciał' . Cechy biologiczne wpływają bowiem

${ }^{3}$ Zob. W. Piątkowski, L. Nowakowska, Socjologia ciała - zarys historii rozwoju subdyscypliny, w: Jedna nauka wiele historii. Dzieje subdyscyplin socjologicznych w Polsce, red. P. Łuszczenko, D. Wincenty, Wydawnictwo Uniwersytetu Gdańskiego, Gdańsk 2010, s. 180-183.

${ }^{4}$ H. Jakubowska, Socjologia ciała, Wydawnictwo Naukowe UAM, Poznań 2009, s. 15.

${ }^{5}$ M. Weber, Etyka protestancka i duch kapitalizmu, tłum. i wstęp D. Lachowska, Wydawnictwa Uniwersytetu Warszawskiego, Warszawa 2011.

${ }^{6}$ M. Featherstone, The Body in Consumer Culture, „Theory, Culture \& Society” 1982, t. 1, nr 2, s. $18-33$.

7 Tamże, s. 18- 19. 
w sposób pośredni na charakter zjawisk społeczno-ekonomicznych, określając zapotrzebowanie na określone dobra, takie jak np. wspomniane już kosmetyki, usługi trenerów personalnych, catering dietetyczny itp. To właśnie cechy biologiczne, czyli płeć czy wiek, oddziałują na kształtowanie określonych wzorów, także tych związanych z cielesnością ${ }^{8}$. Szczególnie istotne są zmiany związane ze starzeniem się organizmu, które pociągają za sobą zmiany w fizjonomii i wyglądzie jednostki, jak choćby siwienie włosów, pojawianie się zmarszczek, plam starczych, pochylenie sylwetki czy drżenie rąk. Charakterystyczne dla procesu starzenia przemiany fizyczne wywierają wpływ na psychologiczny wymiar życia jednostki, jej samoakceptację i samopoczucie ${ }^{9}$. Czynnikiem, który nasila „ciałocentryczność”, jest kultura konsumpcyjna i towarzyszący jej przekaz medialny promujący specyficzny dla współczesności „kult” młodego, sprawnego i pięknego ciała, niejednokrotnie utożsamiająca zdrowie z fizyczną atrakcyjnością ${ }^{10}$. Współczesny człowiek dbałość o kondycję fizyczną, walkę z otyłością czy dietetyczne wskazówki traktuje jako podstawowy wymiar swojej jednostkowej tożsamości ${ }^{11}$.

Drugą ważną przyczyną, która wpłynęła na naukowe i potoczne zainteresowanie ciałem oraz cielesnością, jest ruch feministyczny, zarówno akademicki, jak i przyjmujący postać ruchu społecznego. Działalność feministek przyczyniła się do zainteresowania się ciałem jako źródłem podporządkowania ${ }^{12}$. W klasycznych koncepcjach feministycznych jest ono postrzegane $\mathrm{z}$ dwóch zasadniczych perspektyw. W pierwszej ciało kobiety jest traktowane jako przyczyna jej opresji, druga zakłada możliwości zmiany determinant biologicznych ${ }^{13}$. Pierwszy nurt, głoszący tezę o obciążeniu biologicznym kobiety, reprezentują przede wszystkim publikacje Simone de Beauvoir. W swojej pracy Druga płeć przedstawia ciało kobiety jako podstawową determinantę podrzędnej sytuacji kobiet. Zarówno kobietę, jak i mężczyznę postrzega jako ciało. Ono właśnie określa - jej zdaniem - funkcjonowanie ludzi w społeczeństwie. Tym, co obciąża kobietę, są funkcje rozrodcze, które sprawiają, że jest ona bardziej narażona na wpływ biologii niż mężczyzna ${ }^{14}$. S. de Beauvoir analizowała sytuację kobiety z punktu widzenia indywidualnej jednostki, inną perspektywę - kulturowo-społeczną prezentowała Sherry Ortner. Rozważała ona zjawisko uniwersalnego zdomino-

${ }^{8}$ H. Jakubowska, Socjologia..., s. 21; W. Piątkowski, L. Nowakowska, Socjologia ciała..., s. 180-181.

9 A. Dziuban, Społeczny obraz starości i postrzeganie własnego ciała w procesie starzenia się. Przegląd piśmiennictwa, „Gerontologia Polska” 2010, t. 18, nr 3, s. 140-147.

${ }_{10}$ M. Featherstone, The body in consumer culture..., 22.

${ }_{11}$ C. Schilling, The body and the social theory, Sage Publications, London 1993, s. 15-17.

12 H. Jakubowska, Socjologia..., s. 20.

${ }_{13}$ A. Buczkowski, Społeczne tworzenie ciała, płeć kulturowa i płeć biologiczna, Universitas, Kraków 2005, s. 40.

${ }^{14}$ S. de Beauvoir, Druga płeć, tłum. G. Mycielska, M. Leśniewska, Wydawnictwo Literackie, Kraków 1972, s. 77-80. 
wania kobiety w społeczeństwie. Za punkt wyjścia w swoich analizach przyjęła podział na naturę, będącą stałym i niezależnym elementem egzystencji, i kulturę, obciążoną zmiennością. Przyjęcie takiego założenia doprowadziło S. Ortner do poglądu, zgodnie z którym to płeć biologiczna jest odpowiedzialna za nierówności panujące pomiędzy kobietami a mężczyznami. Owo podporządkowanie płci biologicznej kobiety wynika jej zdaniem z podporządkowanej pozycji natury względem kultury ${ }^{15}$.

Trzecim czynnikiem odpowiedzialnym za wzrost zainteresowania ciałem jest postęp $\mathrm{w}$ technologii i nauce. Technicyzacja życia wiąże się z dostrzeganiem cielesności tak w wymiarze zbiorowej, jak i indywidualnej egzystencji. Konsekwencją tej fascynacji jest rozwój „biowładzy”, a także „społeczeństwa somatycznego", w którym ciało staje się głównym polem aktywności naukowej, politycznej i kulturowej ${ }^{16}$. Wraz z postępującym rozwojem gospodarczym dostrzeżono bowiem wartość ciała jako narzędzia przyspieszającego ten rozwój. W tym kontekście pojawia się zagadnienie „biowładzy”, o którym pisał m.in. Paul Michel Foucault, dostrzegając dwa bieguny „biowładzy”. W pierwszym ciało postrzegane jest jako maszyna podlegająca prawom takim jak tresowanie, usprawnianie, wzrost użyteczności, co powiązane jest $\mathrm{z}$ transformacją gospodarki oraz zasad organizacyjnych społeczeństw zachodnich ${ }^{17}$. Drugi biegun to jego zdaniem koncentrowanie się na ciele jako gatunku oraz podległych mu mechanizmach reprodukcyjnych, proces ten nazwal "biopolityką populacji”"18. Można zatem powiedzieć, że „biowładza” jest to władza nad biologią, „biopolityka” natomiast jest świadomym wykorzystaniem „biowładzy” w praktyce ${ }^{19}$. Biologiczne aspekty ludzkiej egzystencji wielokrotnie były poddawane prawnej regulacji. Oto kilka przykładów takich norm: zapłodnienie in vitro; ograniczenie czy zakaz aborcji; ograniczenie bądź zakaz stosowania środków antykoncepcyjnych; dopuszczalny wiek uprawiania seksu i zawierania małżeństw; zakaz małżeństw homoseksualnych i poligamii; zakaz eutanazji; zakaz klonowania $\mathrm{i}$ innych manipulacji genetycznych; kontrola psychochirurgii, przymus leczenia (narkomanii, alkoholizmu).

Medykalizacja życia, oznaczająca wzrost wiedzy medycznej i rozwój naukowych technik badania ludzkiego ciała, daje możliwość prawie nieograniczonego

15 S. Ortner, Czy kobieta ma się tak do mężczyzny jak „natura” do „kultury”?, w: Nikt nie rodzi się kobieta, wybór, tłum. i wstęp T. Hołówka, posł. A. Jasińska, Czytelnik, Warszawa 1982, s. 115-116.

16 R. Adams, Michel Foucault. Biopolitics and Biopower, Critical Legal Thinking, 10.05.2017, https:// criticallegalthinking.com/2017/05/10/michel-foucault-biopolitics-biopower/ (dostęp: 27.07.2021).

17 M. Foucault, Nadzorować i karać. Narodziny więzienia, tłum. T. Komendant, Aletheia, Warszawa 2020.

18 Tenże, Narodziny biopolityki, tłum. M. Herer, Wydawnictwo Naukowe PWN, Warszawa 2011; A. Buczkowski, Społeczne tworzenie ciała..., s. 139.

19 L. Zacher, Biowładza i biopolityka (refleksje, przykłady, predykcje), Wiedza - Władza, Lublin 2009, s. 95. 
przekształcania ciała przy użyciu nowoczesnych technologii medycznych, takich jak transplantacje organów czy chirurgia plastyczna. Rodzi przy tym wiele dylematów natury etycznej, dotyczących m.in. eugeniki, granicy życia i śmierci. Efektem medykalizacji jest również to, że kategorie niemedyczne zaczynają być traktowane jako problem biomedyczny, najczęściej jako choroba lub zaburzenie ${ }^{20}$.

Niezależnie jednak od przyczyn zainteresowania ciałem, jako ograniczającym lub przeciwnie - umożliwiającym działanie, doświadczenie ludzkiego ciała jest osobowe. Sfera cielesności stała się inspiracją do podejmowania nowych kwestii lub reinterpretacji „starych” zagadnień w ponowoczesnej rzeczywistości.

\section{Geneza socjologii ciała i przedmiot jej zainteresowań}

Zachodnia socjologia przez długi czas była zdominowana przez racjonalistyczną koncepcję ludzkiego aktora działającego na podstawie racjonalnego wyboru i bez odniesienia do swoich uczuć czy cech fizycznych. Pogląd taki jest zbieżny z kartezjańskim założeniem rozróżnienia i oddzielenia umysłu od ciała ${ }^{21}$. Należy wspomnieć o kilku, głównie kontynentalnych, filozofach, jak Maurice Merleau-Ponty, którzy podkreślali ucieleśnioną naturę ludzkich podmiotów, wchodzących w ścisłe interakcje z przestrzenią (poruszamy się, zajmujemy przestrzeń fizyczną) i czasem (nieustannie myślimy o przeszłości i przyszłości, starzejemy się i mamy skończoną długość życia ${ }^{22}$. Inną, nie mniej ważną przyczynę nikłego zainteresowania ciałem w klasycznej socjologii należy upatrywać w sposobie postrzegania ciała jako czegoś „danego raz na zawsze”, czegoś „naturalnego” i „przed-społecznego”, a tym samym niewymagającego głębszej refleksji teoretycznej ${ }^{23}$. Swoich zwolenników ma też pogląd, że dawni socjologowie zajmowali się wyłącznie zachowaniami, działaniami, interakcjami, strukturami i procesami, które uznaje się za neutralne względem opozycji ciało-dusza ${ }^{24}$.

Ciekawe zestawienie socjologów klasycznych, w dorobku których można odnaleźć wątki zainteresowania ciałem i cielesnością, przedstawił J. Szymczyk w swoim artykule Elementy socjologii ciała. Jak zauważa, w klasycznej myśli społecznej jest obecny namysł, który postrzegał cielesność człowieka jako na-

${ }^{20}$ J. Szymczyk, Elementy socjologii ciała, w: Socjologia medycyny w multidyscyplinarnych badaniach humanizujących biomedycynę, red. M. Skrzypek, Wydawnictwo KUL, Lublin 2013, s. 208.

${ }^{21}$ H. Jakubowska, Socjologia ciała..., s. 105-107.

22 Ch. Ozawa-de Silva, Beyond the Body/Mind? Japanese Contemporary Thinkers on Alternative Sociologies of the Body, „Body and Society” 2002, t. 8, nr 2, s. 21-38.

23 A. Wieczorkiewicz, Muzeum ludzkich ciał. Anatomia spojrzenia, Wydawnictwo Słowo/obraz, terytoria, Gdańsk 2009, s. 9.

24 J. Szymczyk, Elementy socjologii ciała..., s. 201. 
rzędzie wyjaśniania zjawisk i stosunków społecznych. Lubleski socjolog zgadza się z Chrisem Shillingiem, że tematykę somatyczności należy odkryć we wczesnych pismach socjologicznych i traktować te poszukiwania jako odkrywanie „nieobecnej obecności”. Przykładem takiego „ukrytego dziedzictwa” są rozważania Maxa Webera nad ciałem stanowiącym źródło i lokalizację dla zjawisk ze sfery sacrum, które służą łączeniu jednostki w moralne całości, a także dyskurs dotyczący ascetyzmu. Podobne pierwiastki perspektywy somatycznej można odkryć w analizie samobójstwa w pismach Emile’a Durkheima ${ }^{25}$. J. Szymczyk wskazuje również na takie koncepcje i teorie, jak orientacja organicystyczna, teoria darwinizmu społecznego, nurt rasowo-antropologiczny i socjobiologia, które wyjaśniały reguły świata społecznego w oparciu o inspiracje biologią. Zainteresowanie społecznym kontekstem funkcjonowania ciała można odnaleźć w pismach Marcela Maussa, Norberta Eliasa i Georga Simmela. Pierwszy z autorów traktował cielesności jako obiekt oddziaływań różnych technik zmiennych kulturowo i historycznie. Jego zdaniem zainteresowanie się ciałem przejawiało się w zmieniających się na przestrzeni dziejów społecznie akceptowanych technikach i rytuałach obchodzenia się z ciałem. Przedmiotem zainteresowania N. Eliasa był wpływ przemian cywilizacyjnych na cielesność człowieka. Wskazywał on na proces społecznego oddziaływania na nawet te najbardziej intymne sposoby obchodzenia się z ciałem, które podlegają zinternalizowanej i po części zautomatyzowanej samokontroli, rozumianej jako proces „cywilizowania obsługiwania ciała"26. Z kolei w przekonaniu G. Simmela to właśnie somatyczne popędy i dyspozycje kierują jednostkę do bycia $\mathrm{z}$ innymi ludźmi lub przeciwnie, do bycia przeciw nim ${ }^{27}$.

Zainteresowanie ciałem i cielesnością jest więc obecne w klasycznej socjologii, chociaż wyraźnie można wskazać na dualistyczny charakter tej „nieobecnej obecności”. Po pierwsze sam przedmiot socjologii jest „ucieleśniony” i modyfikowany, kształtowany przez możliwości i ograniczenia płynące z posiadania i bycia ciałem. Klasyczna socjologia nie analizowała zagadnień cielesności w sposób systematyczny, nie przedstawiano w niej szczegółowych, odrębnych badań poświęconych temu zagadnieniu. J. Szymczyk nie zgadza się jednak z obecnym w dyskursie naukowym poglądem zarzucającym dawnej socjologii całkowicie "odcieleśnione" podejście do prowadzonych badań ${ }^{28}$. Z historycznego punktu widzenia można wyróżnić trzy fazy rozwoju socjologii ciała. W pierwszej z nich, ukrytej, reprezentowanej przez klasyków socjologii, rozważania nad znaczeniem ciała nie były wyraźnie doprecyzowane i nie pojawiały się wprost. W drugiej

25 E. Durkheim, Elementarne formy życia religijnego, tłum. i wstęp A. Zadrożyńska, wstęp do wyd. pol. E. Tarkowska, Wydawnictwo PWN, Warszawa 2021.

${ }^{26}$ N. Elias, Przemiany obyczajów w cywilizacji Zachodu, tłum. T. Zabłudowski, PIW, Warszawa 1980.

27 J. Szymczyk, Elementy socjologii ciała..., s. 202-203.

28 Tamże, s. 203. 
zagadnienia te były już bezpośrednio podejmowane, ale nie w usystematyzowany sposób. Wreszcie w fazie trzeciej cielesność badana jest w sposób systematyczny i staje się właściwym tematem badań socjologicznych ${ }^{29}$.

Za początek fazy trzeciej uznaje się publikację książki B. Turnera The Body and Society ${ }^{30}$. Od czasu ukazania się tej pozycji nastąpił znaczący zwrot w kierunku włączenia obrazu aktora społecznego jako ucieleśnionej istoty do analizy społecznej. Zainspirowało to nowe podejścia do takich tematów jak socjologia medycyny, konstytuowanie się jaźni w późnokapitalistycznych społeczeństwach zachodnich oraz ponowne zbadanie aspektów kultury popularnej, tak różnych jak kulturystyka, dietetyka, sport i taniec ${ }^{31}$. W koncepcji B. Turnera cielesność stała się centralną kategorią rozważań, na co wskazują kluczowe pojęcia „społeczeństwa somatycznego” i „zarządzania ciałem”. Społeczeństwo somatyczne charakteryzuje się tym, że większość politycznych i osobistych problemów dotyczy ciała ${ }^{32}$. Aktywność fizyczna, zdrowy styl życia przejawiający się walką z otyłością stały się z jednej strony głównym problemem polityki społecznej, z drugiej - podstawowym wymiarem budowania jednostkowej tożsamości. W tym wymiarze to jednostka jest odpowiedzialna za swoje ciało, zachowanie zdrowia i atrakcyjności fizycznej. Ciało staje się podstawą nie tylko do samookreślenia i utrzymania dobrego samopoczucia, ale i akceptacji społecznej33. Dla B. Turnera zarządzanie ciałem związane jest przede wszystkim z zarządzaniem seksualnością, szczególnie w przypadku kobiet ${ }^{34}$. Zarządzanie ciałem, dostosowywanie jego wyglądu, ale także ubioru do społecznie akceptowanych ideałów oraz obowiązujących wzorców normatywnych jest warunkiem wytworzenia spójnej tożsamości jednostki oraz kompetencji interakcyjnej ${ }^{35}$.

B. Turner, podkreślając konieczność stworzenia subdyscypliny socjologii ciał, wskazał na dwa istotne kierunki jej przyszłych badań. Po pierwsze, postulował badania, które pozwoliłyby zrozumieć funkcjonowanie ciała w przestrzeni społecznej i kulturowej. To konstruktywistyczne (społeczno-kulturowe) ujęcie ciała uznaje istnienie procesów „społecznego projektowania” ludzkiej cielesności ${ }^{36}$. Po drugie, subdyscyplina ta miałaby za zadanie badać świat życia codziennego, skoncentrowany w coraz większym stopniu na ciele. Poza tymi dwoma skrajnymi ujęciami należy wspomnieć o podejściu fenomenologicznym, które kieruje

29 Tamże.

30 A. Howson, D. Inglis, The Body in Sociology. Tensions inside and outside Sociological Thought, „The Sociological Review” 2001, t. 49, nr 3, s. 297-317.

31 Ch. Ozawa-de Silva, Beyond the Body/Mind?..., s. 22.

32 H. Jakubowska, Socjologia ciała..., s. 132.

33 A. Giddens, Stanowienie społeczeństwa. Zarys teorii strukturacji, tłum. S. Amsterdamski, Wydawnictwo Zysk i S-ka, Poznań 2003, s. 424.

34 A. Buczkowski, Społeczne tworzenie ciała..., s. 12.

35 A. Dziuban, Społeczny obraz starości i postrzeganie własnego ciała w procesie starzenia się..., s. 141.

36 J. Szymczyk, Elementy socjologii ciała..., s. 211. 
się założeniami, że osobowość, społeczeństwo i ład symboliczny są kreowane przez pracę ciała ${ }^{37}$.

Zdaniem J. Szymczyka ogólne założenia postrzegania ciała człowieka implikują bardziej szczegółowe podejścia eksploracyjno-poznawcze, które jego zdaniem można stosować w socjologii ciała. Pierwsze podejście traktuje ciało jako pewną rzeczywistość, socjolog w tym podejściu, posługując się danymi empirycznymi (ilościowymi, jakościowymi), opisuje stosowane przez jednostkę określone „praktyki cielesne”. Drugie wyraźnie podkreśla znaczenie związku, jaki łączy ciało z aksjologią. Badacz rozpatruje ciało jako wartość instrumentalną i autoteliczną. Wreszcie ostatnie uwzględnia w badaniach kontekst, otoczenie społeczno-kulturowe ciała, w jakim ono funkcjonuje $\mathrm{e}^{38}$.

Do obszarów zainteresowania socjologii ciała można zaliczyć m.in. badanie jego symbolicznego znaczenia, płciowego zróżnicowania cielesności, związków ciała z relacjami społecznymi, zagadnienia związane ze starością i starzeniem się, kwestie zdrowia i choroby, problematykę ćwiczeń fizycznych w socjologii sportu, traktowania ciała jako swoistego kapitału, kwestie własności i jego „utowarowienia”, a także somatyczności jako obiektu kontroli społecznej ${ }^{39}$. Uprawianie socjologii ciała stanowi odpowiedź na rosnące zainteresowanie ciałem i zapotrzebowanie na analizy dotyczące ludzkiej somatyczności, która tradycyjnie stanowiła obszar badań medycyny i nauk przyrodniczych.

\section{Cielesność w procesie starzenia się}

Współczesna kultura konsumpcyjna promuje „kult” młodego, sprawnego i pięknego ciała. Niestety, często stawia znak równości pomiędzy zdrowiem a fizyczną atrakcyjnością ${ }^{40}$. Wspomniane już techniki upiększające ciało czy diety znacznie częściej oznaczają troskę o autoprezentację, która odzwierciedla społeczne naciski, a nie rzeczywistą dbałość o zdrowie. Ideał ciała promowany w różnego rodzaju przekazach kulturowych jest jasny - kobieta ma być szczupła, o pięknej, proporcjonalnej sylwetce, nieskazitelnej skórze i błyszczących włosach. Mężczyzna z kolei powinien być umięśniony - ale jego muskulatura nie może być nadmierna. W odniesieniu do obu płci występuje jedna cecha wspólna - zafiksowanie na młodośćcl.

37 H. Jakubowska, Socjologia ciała..., s. 132.

38 J. Szymczyk, Elementy socjologii ciała..., s. 211-212.

39 Tamże, s. 214-217.

40 L.A. Wiśniewska, Kult ciała a starość. Refleksje psychologiczne, „Rocznik Andragogiczny” 2014, t. 21, s. 259-270.

41 A. Głębocka, Treści związane z wizerunkiem ciała w przekazach prasowych - na przykładzie miesięczników „Playboy” i „Twój Styl”, w: Tożsamość społeczno-kulturowa płci, red. A. Barska, E. Mandal, Wydawnictwo Uniwersytetu Opolskiego, Opole 2005, s. 75-88. 
Przyznanie tak wielkiego znaczenia ciału skutkuje nadmierną kontrolą nad nim lub wręcz walką z ciałem. Dyscyplinowanie ciała nie służy jednak zdrowiu, a poprawie wszelkich niedoskonałości, także tych wynikających z procesów starzenia $\operatorname{się~}^{42}$. Ciało ma więc zapewniać współczesnemu człowiekowi nie tylko podstawę dobrego samopoczucia, lecz także akceptację społeczną. Wspomniany kult młodego i atrakcyjnego ciała w znacznym stopniu wpływa na społeczne postawy wobec starości oraz znaczenie przypisywane temu okresowi życia. Niestety, współczesna kultura konsumpcyjna nie wykształciła różnych wzorców piękna pozostających w zgodzie z biologicznymi fazami życia ani nie uwzględnia również różnic kulturowych czy choćby geograficznych, mających wpływ na wzorce starzenia się s3 $^{43}$

Poszczególne rasy i narody starzeją się dyferencjalnie (w zależności od rasy, klimatu, stylu życia) lub wzorcowo (typowo dla danego obszaru, jego klimatu i rasy zamieszkującej określone terytorium). Na przykład Eskimosi lub mieszkańcy Środkowej Afryki żyją przeciętnie 30 lat, a 50. rok życia to w tych skrajnych warunkach wiek bardzo zaawansowany. Natomiast Armenia, Azerbejdżan, Gruzja, kraj Hunza, zwany Szczęśliwą Doliną (Himalaje), dolina Vilcambamba w ekwadorskich Andach i Półwysep Bałkański są zamieszkiwane przez długowieczne społeczeństwa. Ich członkowie żyją niejednokrotnie ponad 100 lat, ciesząc się zdrowiem i sprawnością ${ }^{44}$.

Wizerunek ciała, które się starzeje i nie odpowiada standardom konsumpcyjnego piękna i seksualności, jest wypierany z przestrzeni publicznej i mediów. Dzieje się tak dlatego, że naturalne fizyczne przejawy starzenia się sprawiają, iż wiek podeszły często kojarzy się z niedołężnością, zaniedbaniem, rozkładem ciała, fluidalnością, chorobą, śmiercią czy brakiem kontroli nad własnym organizmem $^{45}$. Jest to jednak obraz patologicznego starzenia się. Proces ten może przebiegać w trzech różnych kierunkach: 1) starzenia się zwyczajnego (usual ageing), w przebiegu którego odczuwalne są straty oraz deficyty, ale bez patologii; 2) pomyślnego starzenia się (successful ageing), gdy predyktory starości odgrywają neutralną lub pozytywną rolę, czyli zwalniają proces starzenia się; 3) starzenia się patologicznego (impaired ageing), w trakcie którego szybko postępuje upośledzenie wielu funkcji życiowych organizmu oraz rozwija się tzw. polipatoligia (współwystępowanie licznych jednostek chorobowych) ${ }^{46}$.

42 F.R. Ferraro, J.J. Muehlenkamp, A. Paintner, K. Wasson, T. Hager, F. Hoverson, Aging, Body Image, and Body Shape, „The Journal of General Psychology” 2008, t. 135, nr 4, s. 379-392.

43 Ch. Ozawa de Silva, Beyond the Body/Mind?..., s. 27-29.

${ }^{44}$ M. Brzezińska, Proaktywna starość. Strategie radzenia sobie ze stresem $w$ okresie późnej dorosłości, Difin, Warszawa 2011, s. 16-17.

45 A. Dziuban, Społeczny obraz starości i postrzeganie własnego ciała w procesie starzenia się..., s. 142.

46 M.E. Mianowany, I. Maniecka-Bryla, W.K. Drygas, Starzenie się populacji jako ważny problem zdrowotny i społeczno-ekonomiczny, „Gerontologia Polska” 2004, t. 12, nr 4, s. 172-176. 
Rozbieżność między propagowanym obrazem cielesności a realnością starzejącego się ciała często wiąże się z procesem stygmatyzacji czy stereotypizacji osób starszych i destrukcyjnie wpływa na ich relacje społeczne i status. Jak sugeruje Ewa Miszczak, współczesne normy dotyczące piękna prowadzą do braku akceptacji dla osób w podeszłym wieku, postrzeganych jako „brzydkie" ${ }^{37}$.

\section{Cielesność a turystyka sportowa}

W twórczości J. Szymczyka ważne miejsce zajmuje zagadnienie sportu i turystyki, które wspomniany autor ściśle wiąże z pojęciem cielesności. Ciało jako przedmiot namysłu naukowego jest szczególnie obecne w tych jego pracach, które poświęcone są aktywności fizycznej rozpatrywanej w kontekście aktywności sportowej, turystycznej i zdrowotnej. Analizując zagadnienie cielesności z perspektywy wspomnianych aktywności, J. Szymczyk wychodzi od rozumienia ciała jako swoistego kapitału (biologicznego) fizycznego. W swoich rozważaniach autor ten łączy kapitał fizyczny z klasycznym „utowarowieniem” ciała, które może być sprzedawane i kupowane jako siła robocza. Kwestie „utowarowienia" ciała często koncentrują się na prawie do jego kontroli lub własności. Nie są one niczym nowym w dyskursie społecznym, od dawna bowiem ciało było uznawane przez teoretyków stosunków własności za fundamentalny obiekt własności ${ }^{48}$. J. Szymczyk przede wszystkim jednak łączy swoje analizy z podejściem zaproponowanym przez Pierre’a Bourdieu, w którym ludzka cielesność staje się nośnikiem władzy, statusu społecznego i różnych symbolicznych dystynkcji niezbędnych w procesie gromadzenia zasobów i przywilejów ${ }^{49}$. Dla francuskiego socjologa ciało było istotnym elementem zróżnicowania społecznego $\mathrm{w}$ tym znaczeniu, w którym dokonuje się jego rangowania $\mathrm{z}$ uwagi na jego walory cenione przez określone społeczno-kulturowe „rynki” ${ }^{50}$. Ciało jest więc dla P. Bourdieu symbolicznym nośnikiem znaczeń i kapitałem fizycznym. Wiąże się to z możliwościami, jakie niosą ze sobą biologiczne zasoby jednostki, takie jak choćby jego piękno, siła czy atletyczna budowa. Zasoby te mogą być bowiem konwertowane w inne formy kapitału: społecznego, materialnego czy

${ }^{47}$ E. Miszczak, Stereotypowy obraz człowieka starszego w Polsce, w: Starość i starzenie się jako doświadczenie jednostek i zbiorowości ludzkich, red. J. Kowaleski, P. Szukalski, Zakład Demografii UŁ, Łódź 2006, s. 305-311.

48 S. Kozyr-Kowalski, Socjologia, społeczeństwo obywatelskie i państwo, Wydawnictwo Naukowe UAM, Poznań 2004, s. 121.

49 J. Szymczyk, Elementy interdyscyplinarnej kooperacji socjologii ciała, sportu i turystyki, w: Podstawy interdyscyplinarności w naukach o zdrowiu. Poznawcza tożsamość dyscyplin badających socjokulturowy wymiar zdrowia i choroby, red. M. Skrzypek, Wydawnictwo KUL, Lublin 2014, s. 114.

50 P. Bourdieu, Dystynkcja. Społeczna krytyka władzy sq̨dzenia, tłum. P. Biłos, Wydawnictwo Naukowe Scholar, Warszawa 2005, s. 44. 
kulturowego. To właśnie w momencie, kiedy kapitał fizyczny zostanie połączony z innymi kapitałami, które nim zarządzają, staje się znaczący. J. Szymczyk zgadza się z podnoszonym w literaturze przedmiotu poglądem, że dysponowanie innymi kapitałami pozwala na przekształcalność i odwracalność różnych elementów kapitału fizycznego. Jak konstatuje, „ciało jako rodzaj kapitału biologicznego stanowi sferę, w którą inwestuje się czas, pieniądze i w konsekwencji czerpie się ewentualne korzyści" ${ }^{51}$.

Zagadnieniem nierozerwalnie związanym z ludzką somatycznością jest aktywność fizyczna, której podstawowymi formami są kategorie sportu i turystyki. W swoich rozważaniach nad socjologicznym ujęciem aktywności sportowej J. Szymczyk wskazuje na jej związek z socjologią ciała poprzez eksponowanie biologiczno-naturalnego wymiaru człowieka. Podkreśla również korelację sportu z generalnie ujmowaną kulturą, gdyż stanowi on część kultury fizycznej, będącej jednym $\mathrm{z}$ aspektów kultury $\mathrm{w}$ szerokim rozumieniu ${ }^{52}$. Istnieje wiele kontrowersji dotyczących określenia istoty sportu, lubelski badacz przyjmuje jednak trzy konstytutywne cechy tej aktywności, zwłaszcza zaś sportu zawodowego: rywalizacjonizm, perfekcjonizm i kreatywnośćc ${ }^{53}$. Omawiając somatyczny aspekt aktywności sportowej, J. Szymczyk wskazuje nie tylko na walory estetyczne ciała sportowców, utożsamiane z ideałem piękna i sprawności. Zwraca również uwagę na dyscyplinowanie ciała. Doskonale wyćwiczone ciało decyduje o sukcesie w sporcie, „w którym liczy się precyzja, elegancja i energia wykonania danej czynności, przez co kolejne bariery ludzkich możliwości bywają sukcesywnie pokonywane w ramach bicia różnych rekordów" ${ }^{\prime 2}$. Jak zauważa, w sporcie ciało stało się swoistym narzędziem pracy, a uwzględniając wymiar ekonomiczny sportu, jest „towarem”, który przekłada się na komercjalizację sportu poprzez zwycięstwo w rozgrywkach, bicie rekordów, zdobywanie medali.

Ciekawym wątkiem prowadzonych przez J. Szymczyka analiz łączących socjologię ciała $\mathrm{z}$ aktywnością sportową i turystyczną jest konstatacja, że aktywność turystyczna podobnie jak sportowa wymaga odpowiedniej kondycji fizyczno-somatycznej człowieka. Proponuje on ujęcie turystyki jako zamierzonej, celowo dobranej do potrzeb człowieka aktywności, która przejawia się w różnych formach wykorzystujących poruszanie się w przestrzeni za pomocą: - naturalnych ruchów lokomocyjnych (np. piesza turystyka nizinna, górska); - sprzętu i techniki sportowej służących przemieszczaniu się w terenie (turystyka kajakowa, żeglarska, rowerowa, motorowa, konna, narciarska $)^{55}$.

${ }^{51}$ J. Szymczyk, Elementy interdyscyplinarnej kooperacji socjologii ciała, sportu i turystyki..., s. 115.

${ }_{22}$ Tenże, Elementy kultury i sportu z perspektywy aksjologii. W kręgu myśli Stanisława Kowalczyka, „Roczniki Nauk Społecznych” 2021, t. 4, nr 1, s. 81-106.

${ }_{53}$ Tenże, Elementy interdyscyplinarnej kooperacji socjologii ciała, sportu i turystyki..., s. 120.

54 Tamże, s. 121.

55 Tamże, s. 127. 
Szczególne związki pomiędzy aktywnością fizyczną a turystyką występują - zdaniem J. Szymczyka - w turystyce aktywnej, której celem jest uczestnictwo w ramach podróży turystycznej w różnych formach rekreacji ruchowej, ukierunkowanych na rozwój sprawności fizycznej i intelektualnej ${ }^{56}$. Szczególnie turystyka kwalifikowana, wymagająca od uczestników umiejętności i sprawności fizycznych oraz kwalifikacji, wykazuje związek z dyscyplinowaniem ciała, co zbliża ją do sportu ${ }^{57}$.

\section{Zakończenie}

Twórczość J. Szymczyka to konglomerat myśli i rozważań związanych m.in. z człowiekiem i jego aktywnością. Autor w swych dociekaniach naukowych odpowiedział na rosnące zapotrzebowanie prowadzenia analiz dotyczących ludzkiej somatyczności, która przekroczyła granice badań nauk medyczno-przyrodniczych. Istotne miejsce zajmują tu analizy poświęcone ludzkiej cielesności, której nie można wyjaśnić wyłącznie za pomocą czynników społecznych ani też analizować jako czegoś istniejącego poza społeczeństwem. Cielesność jest dla niego jednocześnie społeczna i biologiczna, co oczywiście niesie ze sobą pewne konsekwencje ${ }^{58}$. Po pierwsze, ciało w miarę swojego rozwoju do pewnego stopnia podlega modyfikowaniu, (re)konstrukcjom, jak stwierdzają socjologowie ciała, jest projektem. Po drugie, jest ono „wplątane” w formowanie tożsamości, rozwój społeczności, jej przekształcanie, a także reprodukowanie społecznych nierówności. Wynikają one z pierwszej konsekwencji, tzn. ze stopnia i zakresu, w jakim jednostki są w stanie traktować ciało jako projekt. Odnosząc się do tych konsekwencji, lubelski socjolog wyraźnie stwierdza, że prowadząc analizy z zakresu socjologii ciała, nie można pomijać takich istotnych kwestii jak jednostkowe zróżnicowanie doświadczenia somatyczności, podejmowanie praktyk, w których ciało traktowane jest nie tylko przez kulturowe reprezentacje, lecz także w kontekście swojej materialności i biologiczności ${ }^{59}$.

Rozważania z zakresu socjologii ciała prowadzone są przez J. Szymczyka z wnikliwością i krytycznym namysłem. Gdyby nie przedwczesna śmierć autora, na pewno rozwijałyby się w interesujące koncepcje. Analiza pism lubelskiego badacza poświęconych wprost zagadnieniu somatyczności pozwala stwierdzić, że ciało człowieka w jego rozumieniu to kapitał biologiczny stanowiący istotny element kreacji tożsamości jednostki. Szczególne miejsce w tych rozważaniach zajmuje sport i powiązane $\mathrm{z}$ nim praktyki dyscyplinowania i modelowania somatyczności. To zainteresowanie sportem jako zmaganiem się z własną

\footnotetext{
56 T. Łobożewicz, G. Bieńczyk, Podstawy turystyki, WSE, Warszawa 2001, s.132.

57 J. Szymczyk, Elementy interdyscyplinarnej kooperacji socjologii ciała, sportu i turystyki..., s. 128.

58 Tenże, Elementy socjologii ciała..., s. 222.

59 Tamże.
} 
słabością i przekraczaniem własnych granic nasuwa skojarzenia z kodeksem moralności antycznych Greków, który wymagał od nich dbałości o przymioty ducha i nie mniejszej dbałości o ciało, a przede wszystkim o zdrowie, sprawność fizyczną i siłę ${ }^{60}$.

\section{Bibliografia}

Adams R., Michel Foucault. Biopolitics and Biopower, Critical Legal Thinking, 10.05.2017, https:// criticallegalthinking.com/2017/05/10/michel-foucault-biopolitics-biopower/ (dostęp: 27.07.2021).

Andrews D.L., Desperately Seeking Michel. Foucault's Genealogy, the Body, and Critical Sport Sociology, "Sociology of Sport Journal” 1993, t. 10, nr 2, s. 148-167, DOI: 10.1123/ssj.10.2.148.

Bourdieu P., Dystynkcja. Społeczna krytyka władzy sq̨dzenia, tłum. P. Biłos, Wydawnictwo Naukowe Scholar, Warszawa 2005.

Brzezińska M., Proaktywna starość. Strategie radzenia sobie ze stresem w okresie późnej dorosłości, Difin, Warszawa 2011.

Buczkowski A., Społeczne tworzenie ciała, płeć kulturowa i płeć biologiczna, Universitas, Kraków 2005. de Beauvoir S., Druga płeć, tłum. G. Mycielska, M. Leśniewska, Wydawnictwo Literackie, Kraków 1972.

Durkheim E., Elementarne formy życia religijnego. System totemiczny w Australii, tłum. i wstęp A. Zadrożyńska, wstęp do wyd. pol. E. Tarkowska, Wydawnictwo Naukowe PWN, Warszawa 2021.

Dziuban A., Społeczny obraz starości i postrzeganie własnego ciała w procesie starzenia się. Przegląd piśmiennictwa, "Gerontologia Polska” 2010, t. 18, nr 3, s. 140-147.

Elias N., Przemiany obyczajów w cywilizacji Zachodu, tłum. T. Zabłudowski, PIW, Warszawa 1980.

Featherstone M., The Body in Consumer Culture, "Theory, Culture \& Society” 1982, t. 1, nr 2, s. 18-33, DOI: $10.1177 / 026327648200100203$.

Ferraro F.R., Muehlenkamp J.J., Paintner A., Wasson K., Hager T., Hoverson F., Aging, Body Image, and Body Shape, "The Journal of General Psychology" 2008, t. 135, nr 4, s. 379-392.

Foucault M., Nadzorować $i$ karać. Narodziny więzienia, tłum. T. Komendant, Aletheia, Warszawa 2020. Foucault M., Narodziny biopolityki, tłum. M. Herer, Wydawnictwo Naukowe PWN, Warszawa 2011. Gawroński J., Do źródła Muz. Greckie wrażenia dyletanta, Instytut Wydawniczy PAX, Warszawa 1970.

Giddens A., Stanowienie społeczeństwa. Zarys teorii strukturacji, tłum. S. Amsterdamski, Wydawnictwo Zysk i S-ka, Poznań 2003.

Głębocka A., Treści zwiq̨zane z wizerunkiem ciała w przekazach prasowych - na przykładzie miesięczników "Playboy" $i$ „,Twój Styl”, w: Tożsamość społeczno-kulturowa płci, red. A. Barska, E. Mandal, Wydawnictwo Uniwersytetu Opolskiego, Opole 2005, s. 75-88.

Howson A., Inglis D., The Body in Sociology. Tensions inside and outside Sociological Thought, ,The Sociological Review" 2001, t. 49, nr 3, s. 297-317, DOI: 10.1111/1467-954X.00333.

Jakubowska H., Socjologia ciała, Wydawnictwo Naukowe UAM, Poznań 2009.

Kozyr-Kowalski S., Socjologia, społeczeństwo obywatelskie i państwo, Wydawnictwo Naukowe UAM, Poznań 2004.

Piątkowski W., Nowakowska L., Socjologia ciała - zarys historii rozwoju subdyscypliny, w: Jedna nauka wiele historii. Dzieje subdyscyplin socjologicznych w Polsce, red. P. Łuszczenko, D. Wincenty, Wydawnictwo Uniwersytetu Gdańskiego, Gdańsk 2010, s. 179-194.

Łobożewicz T., Bieńczyk G., Podstawy turystyki, WSE, Warszawa 2001.

Mianowany M.E., Maniecka-Bryla I., Drygas W.K., Starzenie się populacji jako ważny problem zdrowotny i społeczno-ekonomiczny, "Gerontologia Polska" 2004, t. 12, nr 4, s. 172-176.

${ }^{60}$ J. Gawroński, Do źródła Muz. Greckie wrażenia dyletanta, Instytut Wydawniczy PAX, Warszawa 1970, s. 44. 
Miszczak E., Stereotypowy obraz człowieka starszego w Polsce, w: Starość i starzenie się jako doświadczenie jednostek i zbiorowości ludzkich, red. J. Kowaleski, P. Szukalski, Zakład Demografii Ut, Łódź 2006, s. 305-311.

Ortner S., Czy kobieta ma się tak do mężczyzny jak "natura” do „kultury”?, w: Nikt nie rodzi się kobieta, wybór, tłum. i wstęp T. Hołówka, posł. A. Jasińska, Czytelnik, Warszawa 1982, s. 112-141.

Ozawa-de Silva Ch., Beyond the Body/Mind? Japanese Contemporary Thinkers on Alternative Sociologies of the Body, ,"Body and Society" 2002, t. 8, nr 2, s. 21-38, DOI: 10.1177/1357034X02008002002.

Schilling Ch., The Body and the Social Theory, Sage Publications, London 1993.

Szymczyk J., Elementy interdyscyplinarnej kooperacji socjologii ciała, sportu i turystyki, w: Podstawy interdyscyplinarności w naukach o zdrowiu. Poznawcza tożsamość dyscyplin badających socjokulturowy wymiar zdrowia i choroby, red. M. Skrzypek, Wydawnictwo KUL, Lublin 2014, s. 113-136.

Szymczyk J., Elementy kultury i sportu z perspektywy aksjologii. W kręgu myśli Stanisława Kowalczyka, "Roczniki Nauk Społecznych” 2021, t. 4, nr 1, s. 81-106.

Szymczyk J., Elementy socjologii ciała, w: Socjologia medycyny w multidyscyplinarnych badaniach humanizujacych biomedycynę, red. M. Skrzypek, Wydawnictwo KUL, Lublin 2013, s. 197-222.

Weber M., Etyka protestancka i duch kapitalizmu, tłum. i wstęp D. Lachowska, Wydawnictwa Uniwersytetu Warszawskiego, Warszawa 2011.

Wieczorkiewicz A., Muzeum ludzkich ciał. Anatomia spojrzenia, Wydawnictwo słowo/obraz, terytoria, Gdańsk 2009.

Wiśniewska L.A., Kult ciała a starość. Refleksje psychologiczne „Rocznik Andragogiczny” 2014, t. 21, s. 259-270, DOI: 10.12775/RA.2014.019.

Womack, M. The Anthropology of Health and Healing, AltaMira Press, Lanham-New York-Toronto-Plymouth UK 2010.

Zacher L.W., Biowładza i biopolityka (refleksje, przykłady, predykcje), w: Wiedza - władza, red. J. Szymczyk, M. Zemło, A. Jabłoński, Wydawnictwo KUL, Lublin 2009, s. 94-100.

\section{Streszczenie}

Celem artykułu jest przedstawienie refleksji Jana Szymczyka poświęconych ludzkiej cielesności i związkom somatyczności ze sportem i turystyką. W niektórych pismach J. Szymczyk poddaje systematycznej refleksji status ciała w ponowoczesności i prezentuje powiązania cielesności ze sportem, turystyką. Podobnie jak inni teoretycy, Szymczyk dostrzegał silne korelacje ludzkiej cielesności z formami aktywności fizycznej, takimi jak sport i turystyka. Prezentowany artykuł podejmuje próbę przedstawienia dorobku Autora właśnie w tej dziedzinie, ze szczególnym uwzględnieniem wielopłaszczyznowych zależności pomiędzy turystyką a sportem, szczególnie w przypadku turystyki kwalifikowanej. W artykule omówiono genezę rozwoju subdyscypliny socjologii ciała, determinanty jej rozwoju, przedmioty jej zainteresowania, wreszcie autorski wkład Jana Szymczyka w wykazanie związku pomiędzy sportem, turystyką a wspomnianą subdyscypliną socjologii.

Słowa kluczowe: socjologia ciała, podeszły wiek, aktywność fizyczna, turystyka

\section{The Body and Sport in the Work of Jan Szymczyk in the Context of Classical and Contemporary Concepts of Body Sociology}

\section{Summary}

The aim of this article is to present Jan Szymczyk's reflections on human corporeality and the relationship of somatization with sport and tourism. In some of his writings, Szymczyk systematically 
reflects on the status of the body in postmodernity and presents links between corporeality, sport and tourism. Like other theoreticians, Szymczyk noticed strong correlations of human corporeality with forms of physical activity such as sport and tourism. The article attempts to present the author's achievements in this field, with particular emphasis on the multifaceted relations between tourism and sport, especially in the case of qualified tourism. The article discusses the development of the sub-discipline of sociology of the body, the objects of the sub-discipline, and finally Jan Szymczyk's own efforts to prove the connection between sport, tourism and the mentioned sub-discipline of the sociology of the body.

Key words: sociology of the body, old age, physical activity, tourism 